11. Нечипоренко С.Д. Сутність та значення соціального страхування в системі соціального захисту населення. Агросвіт. 2017. № 6. С. 55-60.

12. Про дипломатичну службу : Закон України від 07.06.2018 № 2449-VIII. Вiдомості Bepховної Ради України (ВВР). 2018. № 50. С. 7.

13. Про затвердження Порядку надання державним службовцям матеріальної допомоги для вирішення соціально-побутових питань : Постанова Кабінету Міністрів України від 08.08.2016 № 500. Офічіийний вісник України. 2016. № 65. С. 44.

14. Про упорядкування здійснення компенсаційних виплат в іноземній валюті та оплати інших витрат працівникам дипломатичної служби України, направленим у довготермінове відрядження : Постанова Кабінету Міністрів України від 17.04.2019 № 332. Офіиійний вісник України . 2019. № 34. C. 284.

УДК 349.3

DOI https://doi.org/10.32844/2618-1258.2019.5-1.14

ВІЖУНОВ О.В.

\title{
ДОКТРИНАЛЬНІ ПІДХОДИ ДО РОЗУМІННЯ ПОНЯТТЯ «ОСОБА 3 ІНВАЛІДНІСТЮ»
}

\begin{abstract}
У статті досліджуються основні теоретико-правові підходи до розуміння «особа 3 інвалідністю». Основна увага приділяється питанням щодо поняття соціального захисту осіб з інвалідністю. Розкриваються науково-теоретичні підходи. Аналізуються і досліджуються положення чинного законодавства про права осіб з інвалідністю. 3'ясовано, що Всесвітня організація охорони здоров'я рекомендує розглядати інвалідність як біосоціальну категорію, і проблеми інвалідності повинні розв'язуватися з біологічної, особистісної та соціальної позицій. Визначено, що людина з інвалідністю - це індивід, який має уроджені чи набуті приховані чи характерні ознаки розладу здоров'я, які обмежують життєдіяльність людини, що призводить до соціального захисту для повноцінного функціонування в суспільстві. Констатовано наявність великої кількості понять, які аналогічні терміну «інвалід», за допомогою якого визначається характеристика стану людини, ії відносять до особливої групи суспільства, що потребує сторонньої допомоги з його боку та боку оточуючих, оскільки самостійно не може себе обслуговувати та повноцінно жити. Зроблено висновок, що протягом останніх десятиліть у визначення поняття «інвалідність» вкладався різний зміст. На початку воно означало функціональне порушення органів чуття або фізичні недоліки, згодом трансформувавшись у несприятливе становище, опинившись у якому, людина з інвалідністю потребує підтримки. Так, інвалідність $є$ соціальним ризиком, що в контексті права соціального забезпечення означає становище людини, на подолання або зниження негативного впливу якого спрямований соціальний захист. Термін «людина 3 інвалідністю» включає у себе низку аспектів: а) наявність у людини певних медико-біологічних або психологічних обмежень, які негативно впливають на неї, ускладнюючи можливість повноцінного виконання широкого кола соціальних функцій, зокрема і комунікацію з оточуючими; б) специфічний правовий статус, який визначається законодавчими актами та додатковими документами, виданими людині індивідуально для підтвердження іiї статусу; в) сформоване під тиском та впливом історичних та етнічних особливостей ставлення до неї з боку оточення та соціуму в цілому.

Ключові слова: сочіальний захист, сочіальне забезпечення, види сочіального забезпечення, соиіальні ризики, особи з інвалідністю, право на сочіальне забезпечення, законодавство про права осіб з інвалідністю.
\end{abstract}

(C) ВІЖУНОВ О.В. - здобувач кафедри правознавства (Східноукраїнський національний університет імені Володимира Даля) 
The article explores the basic theoretical and legal approaches to the understanding of "person with disability". The focus is on the concept of social protection for persons with disabilities. Scientific and theoretical approaches are revealed. The current legislation on the rights of persons with disabilities is analyzed and examined. It has been found that the World Health Organization recommends considering disability as a biosocial category and that disability issues should be addressed from a biological, personal and social point of view. It is determined that a person with a disability is an individual who has congenital or acquired latent or characteristic signs of a health disorder that limits a person's life, leading to social protection for full functioning in society. The existence of a large number of concepts similar to the term "disabled", by which the characterization of a person's condition is determined, is referred to a special group of society that needs outside help from his or her side, as they cannot support themselves and live fully on their own. It is concluded that over the past decades, various meanings have been incorporated into the definition of "disability". Initially, it meant a functional impairment of the sense organs or physical disabilities, subsequently transforming into a disadvantage, finding itself in which a person with a disability needed support. Yes, disability is a social risk, which in the context of social security rights means the situation of a person whose social protection is addressed or mitigated by the negative impact. The term "person with disability" includes a number of aspects: a) the presence in the person of certain medical, biological or psychological restrictions that adversely affect it, complicating the possibility of full performance of a wide range of social functions, including communication with others; b) specific legal status, which is determined by legislative acts and additional documents issued to a person individually to confirm his status; c) formed under the pressure and influence of historical and ethnic peculiarities of attitudes towards it from the environment and society as a whole.

Key words: social protection, social welfare, types of social security, social risks, persons with disabilities, right to social security, legislation on the rights of persons with disabilities.

Вступ. У Конвенції про права осіб з інвалідністю наводяться такі дані: у середньому щонайменше кожен десятий мешканець світу має фізичні, розумові або сенсорні дефекти, а близько $25 \%$ будь-якої групи населення відчувають на собі негативні впливи цього явища [1]. За даними Центру перспективних соціальних досліджень Міністерства соціальної політики України та НАН України, в Україні офіційно зареєстровано понад 2,8 мільйона осіб, що мають статус людини з інвалідністю. Це близько 6,1\% від загальної кількості населення [2, с. 240].

Постановка завдання. Метою статті $\epsilon$ аналіз підходів до розуміння терміна «особа 3 інвалідністю» та визначення його характерних критеріїв.

Результати дослідження. Слід звернути увагу на те, що одночасно з поняттями «інвалід», «інвалідність» використовуються у побутовій мові, спеціальній фаховій та науковій літературі, засобах масової інформації, у практичній роботі юристів, соціальних працівників, психологів, соціальних педагогів такі дефініції, як «люди з особливими потребами», «люди з обмеженими фізичними можливостями», «люди з функціональними обмеженнями», «люди з інвалідністю», «люди з обмеженнями життєдіяльності». Крім цього, стосовно різних груп осіб з інвалідністю використовуються й інші терміни: «неповносправні», «особи з фізичними та/або розумовими вадами», «діти-інваліди», «дефектні діти», «нетипові діти», «аномальні діти», «неповноцінні діти», «діти зі специфічними потребами», «діти з труднощами в навчанні» тощо [3, с. 272].

І хоча ці терміни не $є$ регламентованими на законодавчому рівні, вони активно використовуються, досить часто вживаються, що вказує на те, що дані дефініції еволюціонують [4, с. 240].

Розвиваючи цю думку, цікавими щодо термінології видаються міркування Джона Джойнеpa, що семантика слова disabled - недієздатний стає причиною формування в оточуючих відповідного ставлення до таких людей, а це впливає на становище самих інвалідів. Учений пропонує називати таких людей протилежним словом abled people або people with abilities, тобто людьми, які мають здібності й потребують особливих умов для їх розвитку [5].

Останнім часом у міжнародному спілкуванні слово «інвалід» майже не вживається. Вважається, що воно принижує людську гідність, підкреслює нездатність особистості до повноцінного життя, виконання своїх соціальних і біологічних функцій. Це пов'язано з тим, що ставлення 
до інвалідів у науковій літературі іноді визначалося терміном disabilism - дизабілізм (інвалідизм) за аналогією $з$ терміном «расизм». Дизабілізм передбачає дискримінацію людей з обмеженими психофізичними можливостями і ставлення до них як до неповноцінних [6, с. 79-80].

Таке розуміння проблеми інвалідності домінувало в суспільній свідомості до середини $\mathrm{XX}$ ст. і було характерним для індустріального суспільства, коли людина розглядалася насамперед як виробник матеріальних і духовних благ [7, с. 7].

Поняття «інвалід» еволюціонує і замінюється іншими термінами, але залишається у низці вітчизняних законопроєктів, законодавчих актів, документів міжнародних організацій та окремих країн і має досить глибокі історичні корені [8, с. 191].

Термін «особа з інвалідністю» (від лат. invalid - непридатний) служить для характеристики осіб, які внаслідок захворювання, поранення, каліцтва обмежені в проявах життєдіяльності.

У Великому тлумачному словнику сучасної української мови пропонується визначати інваліда як людину, яка частково чи повністю втратила працездатність унаслідок поранення, хвороби, каліцтва чи старості, а інвалідність є станом інваліда [9, с. 397].

У Словнику російської мови С.І. Ожегова інвалід - людина, яка втратила працездатність унаслідок каліцтва, хвороби [10, с. 214].

Словник іншомовних слід тлумачить інвалідність як нездатність людини працювати за своєю професією чи взагалі - внаслідок захворювання або вродженого дефекту розвитку [11, с. 380].

Юридичний словник інвалідність розкриває як посвідчений медичним органом стан здоров'я, за якого громадянин через хронічне захворювання чи анатомічні дефекти, які спричиняють стійке, незважаючи на лікування, порушення функцій організму, змушує припинити професійну діяльність або може працювати в разі значних змін звичайних умов їхньої праці [12, с. 256-257].

Енциклопедичний словник медичних термінів розкриває зміст інвалідності як стійкої, тривалої або постійної втрати працездатності чи значного ії обмеження, що викликане хронічним захворюванням, травмою або патологічним станом [13, с. 411].

Оксфордський тлумачний словник із психології поняття «інвалід» трактує досить спрощено та поверхнево, там інвалід розглядається як «той, що має недолік, унаслідок якого його здатність до функціонування є меншою за нормальну» [14], хоча саме психологія вивчає психологічні особливості цієї специфічної групи суспільства, а також механізми її взаємодії з іншими групами у загальній системі комунікацій.

У Декларації ООН про права інвалідів (1975 року) пропонується дефініція інваліда як будь-якої особи, що не може самостійно забезпечити повністю або частково потреби нормальної особистості та (або) соціального життя в силу недоліку, будь то вродженого чи ні, його (ii) фізичних чи розумових можливостей [15, с. 244].

У Конвенції ООН про права інвалідів (2006 року) інвалідність трактується як «поняття, яке еволюціонує й $є$ результатом взаємодії, яка відбувається між людьми з інвалідністю та перешкодами у стосунках і середовищі та яка заважає їхній повноцінній і дієвій участі у житті суспільства нарівні з іншими» [16, с. 21].

Така дефініція інвалідності як явища дає можливість розуміти його як таке, що має соціальну природу походження й є проблемою, властивою соціуму в цілому, а не якоїсь відокремленої його групи, що страждає на певні дефекти або вагомі вади здоров'я. Психологічні та фізичні бар'єри, які існують у навколишньому середовищі, загострюють відчуття дискомфорту та почуття меншовартості у людей з інвалідністю [17, с. 244].

Всесвітня організація охорони здоров’я рекомендує розглядати інвалідність як біосоціальну категорію, і проблеми інвалідності повинні розв'язуватися з біологічної, особистісної та соціальної позицій. До того ж не всі люди з обмеженнями життєдіяльності визначаються інвалідами, а лише ті, в кого спостерігаються стійкі довготривалі порушення функцій організму та хто потребує соціальної допомоги [18, с. 275].

«Стандартні правила забезпечення рівних можливостей для інвалідів» визначають інвалідність як «кількість функціональних обмежень, які трапляються серед населення в усіх країнах світу. Люди можуть стати інвалідами внаслідок фізичних, розумових чи сенсорних дефектів, стану здоров’я чи психічних хвороб. Такі дефекти, стани чи захворювання за своїм характером можуть бути постійними або тимчасовими» [19].

Російське законодавство визначає інваліда як особу, що має порушення здоров'я зі стійкими розладами функцій організму, зумовленими захворюваннями, наслідками травм чи дефектами, що призводять до обмеження життєдіяльності, яке викликає необхідність соціального захисту [20, с. 233]. 
Як науковий термін дефініція «інвалід» використовується у різних галузях знань: соціальній педагогіці, медицині, юриспруденції тощо. У цілому він характеризує особу, що через обмеження життєдіяльності з причин фізичних, сенсорних або розумових недоліків потребує соціальної допомоги, підтримки та захисту [21]. У спеціальній педагогіці використовується суміжне поняття «особа з обмеженими психофізичними можливостями (життєдіяльності)», а в контексті навчального процесу - «особа з особливими освітніми процесами» [22].

Заслуговує на увагу визначення, запропоноване представником науки права соціального забезпечення I.M. Сиротою. Згідно з його визначенням, про інвалідність йдеться тоді, коли розлади функцій організму під впливом хвороби чи внаслідок анатомічного дефекту тягнуть за собою соціальні наслідки: припинення професійної діяльності у звичайних умовах чи ії зміна, призначення різних видів соціальної допомоги, встановлення пільг та ін. [23, с. 155].

I.I. Козубом пропонується замінити термін «інвалід» на інше поняття - «особа зі зниженою працездатністю», адже вказаний термін дає змогу розглядати цю категорію осіб саме як таких, що потребують різного роду соціальної допомоги, юридичного захисту, і таких, що водночас $\epsilon$ визначеною мірою працездатними і рівноправними членами соціуму [24].

В.А. Красномовець уважає більш доцільним використовувати термін «особа з обмеженими фізичними можливостями», адже, на думку автора, за його допомогою найбільш повно характеризується така категорія населення, як люди з інвалідністю [25].

Проте, розвиваючи далі цю думку, згаданий учений зазначає, що під час застосовування понять «особа з обмеженими можливостями» та «люди з особливими потребами» в них вкладається дещо ширше значення, ніж до досліджуваної групи людей. Так, на його думку, до категорії осіб з обмеженими можливостями можна віднести й матір чотирьох дітей, можливості економічної активності якої значно обмежені процесом догляду та виховання. До когорти людей з особливими потребами можна включити наркозалежних, потреби яких є специфічними. В.А. Красномовець пропонує таке визначення поняття «людина з обмеженими фізичними можливостями»: це особа з уродженими чи набутими стійкими розладами функцій організму, що потребує допомоги для здійснення повноцінної життєдіяльності, розвитку та інтеграції в суспільство [26]. Так, ученим підкреслюється не лише вади у стані психічного чи фізичного здоров'я досліджуваної категорії суспільства, а й робиться акцент на потребі іiі розвитку та забезпечення для неї умов, за яких іiї представники відчували б себе повноцінними.

У контексті вивчення дітей з інвалідністю аналогічної думки притримується у своєму дослідженні В.С. Тарасенко. Так, учена пропонує внести зміни до національного законодавства: замість різних термінів, які вживаються у нормативно-правових актах, увести єдиний термін - «дитина з обмеженими можливостями» [27].

Як слушно зазначає Р.В. Панасюк, із політично-суспільними перетвореннями на різних етапах історичного розвитку, на що вже деякою мірою зверталася увага на початку підрозділу, щодо визначення та ставлення до осіб з інвалідністю сформувалося коло різних підходів. Наприклад, біомедичний підхід прирівнює інвалідність до хвороби чи вади, яка стосується безпосередньо стану здоров'я індивіда; за філантропічним підходом інвалідність є «людською трагедією», а інвалід - людина, яка потребує співчуття та особливого ставлення до себе; соціологічний підхід робить акцент на відмінності інваліда від соціальних норм, яка обмежує його здатність до повноцінної суспільної життєдіяльності та право мати рівноцінні можливості з іншими членами соціуму; економічний підхід розглядає інвалідність як причину збільшення матеріальних витрат через особливі потреби інваліда та його обмежену працездатність; соціально-політичний підхід трактує інвалідність як наслідок середовища, яке не відповідає можливостям людини. Перші чотири підходи відносять проблему інвалідності лише до сфери проблем самого інваліда, через що зумовлюють появу таких негативних тенденцій у ставленні до інвалідності як переконання у тому, що людина з обмеженими можливостями $є$ обов'язково неповноцінним членом суспільства, яка потребує завжди особливого догляду та допомоги, не $є$ повноцінно працездатною і має обмежені права та можливості для самоактуалізації й соціальної взаємодії. Прихильники соціально-політичного підходу виносять проблему інвалідності за межу сфери життєдіяльності інваліда у сферу загальносуспільних відносин і говорять про те, що саме суспільство $є$ каталізатором виникнення соціально-психологічного явища інвалідності [28, с. 20-21].

Під час характеристики інвалідності людини традиційно фахівці враховують час настання інвалідності, ступінь і якість первинного дефекту (стану чи хвороби), вікові та статеві особливості психофізичного розвитку, ступінь працездатності або непрацездатності [29, с. 81]. 
Н.М. Назарова, займаючись класифікацією інвалідності, справедливо зауважує, що диференціація залежить від галузевої специфіки. Так, існують своєрідні у медицині, юриспруденції, зокрема в медичному праві та праві соціального забезпечення, психології, педагогіці та соціології. Частіше за все як критерії для диференціації використовуються: причини порушень; види порушень із подальшою конкретизацією їх характеру; наслідки порушень, які позначаються в подальшому житті [30].

Аналіз наукової літератури та нормативно-правових документів дає змогу констатувати наявність великої кількості понять, які аналогічні терміну «інвалід», за допомогою якого визначається характеристика стану людини, ії̈ відносять до особливої групи суспільства, що потребує сторонньої допомоги з його боку та боку оточуючих, оскільки самостійно не може себе обслуговувати та повноцінно жити. Однак це поняття, яке виходить зі здійсненого вище аналізу, постійно трансформується й набуває нових рис та особливостей.

Беручи до уваги напрацювання теоретиків різних царин сучасної науки, зокрема права соціального забезпечення, вважаємо за доцільне, по-перше, найбільш удало використовувати категорію «людина із інвалідністю», а не «особа», адже поняття «особа» можна трактувати 3 двох боків - як юридичну особу, так і фізичну, що є абсолютно нелогічним у контексті досліджуваної проблематики.

На нашу думку, людина з інвалідністю - це індивід, який має уроджені чи набуті приховані або характерні ознаки розладу здоров'я, які обмежують життєдіяльність людини, що призводить до соціального захисту для повноцінного функціонування в суспільстві.

Особливий акцент хочемо зробити на необхідності використання у дефініції як терміна «інтеграція», так і «реінтеграція», адже дані особи можуть потребувати як первинного входження у суспільство як повноправних членів, так і повернення до нього, якщо йдеться про інвалідність набуту. Дана ідея запозичена у дисертації А.О. Медвідь, яка, займаючись питанням соціального захисту бездомних осіб і безпритульних дітей, указувала на ці два можливі варіанти [31].

Саме така редакція визначення, на наше переконання, найбільш повно відповідатиме Конвенції ООН про права інвалідів, якою було створено відповідне правове поле для максимально ефективного і справедливого захисту соціальних та інших прав людей з інвалідністю.

Висновки. Слід зазначити, що протягом останніх десятиліть у визначення поняття «інвалідність» вкладався різний зміст. На початку воно означало функціональне порушення органів чуття або фізичні недоліки, згодом трансформувавшись у несприятливе становище, опинившись у якому, людина з інвалідністю потребує підтримки. Так, інвалідність є соціальним ризиком, що в контексті права соціального забезпечення означає становище людини, на подолання або зниження негативного впливу якого спрямований соціальний захист.

Термін «людина з інвалідністю» включає у себе низку аспектів: а) наявність у людини певних медико-біологічних або психологічних обмежень, які негативно впливають на неї, ускладнюючи можливість повноцінного виконання широкого кола соціальних функцій, зокрема і комунікацію з оточуючими; б) специфічний правовий статус, який визначається законодавчими актами та додатковими документами, виданими людині індивідуально для підтвердження ії статусу; в) сформоване під тиском та впливом історичних та етнічних особливостей ставлення до неї з боку оточення та соціуму в цілому.

\section{Список використаних джерел:}

1. Конвенція про права осіб з інвалідністю : Закон № 1767-VI від 16.12.2009. Офіиійний вісник України. 2010. № 17 / №101. Ст. 93.

2. Панасюк Р.В. Еволюційний погляд на дефініцію «інвалідність». Актуальні проблеми психології. 2018. Вип. 45. Т. 7. С. 240-252.

3. Корнієнко С. Теоретичний аналіз спеціального понятійного апарату на відповідність завдання забезпечення прав дітей-інвалідів в Україні. Вісник Національної академії державного управління. Серія «Соціальна і гуманітарна політика». 2011. № 3. С. 271-277.

4. Панасюк Р.В. Еволюційний погляд на дефініцію «інвалідність». Актуальні проблеми психології. 2018. Вип. 45. Т. 7. С. 240-252. 2011. 184 c.

5. Байда Л., Красюкова О. Інвалідність та суспільство : навчальний посібник. Київ,

6. Мілушина М.О. Основні дефініції дослідження осіб з обмеженими фізичними можливостями. Вісник Дніпропетровського університету ім. Альфреда Нобеля. Серія «Педагогіка $і$ психологія». 2013. № 1(5) 80. С. 79-83. 
7. Забрамная С.Д. Ваш ребенок учится во вспомогательной школе: рабочая книга для родителей. Москва : Педагогика, 1990. 320 с.

8. Синьов В.М. Принципи організації системи освітньо-корекційних послуг особам з порушенням інтелекту. Вісник Луганського національного університету імені Т. Шевченка. 2008. № 12(151). С. 7-20.

9. Великий тлумачний словник сучасної української мови / уклад. і гол. ред. В.Т. Бусел. Київ ; Ірпінь : Перун, 2004. 1440 с.

10. Ожегов С.И. Словарь русского язика / под ред. чл.-корр. АН СССР Н.Ю. Шведовой ; 18-е изд., стереотип. Москва : Русский язык, 1986. 620 с.

11. Словник іншомовних слів / за ред. О.С. Мельничука. Київ : Головна редакція Української радянської енциклопедії, 1977. 775 с.

12. Юридичний словник-довідник / за ред. Д.С. Шемшученка. Київ : Феміна, 1996. 694 с.

13. Энциклопедический словарь медицинских терминов : в 3-х т. Т. 1 / под ред. Б.В. Петровского. Москва : Советская энциклопедия, 1982. 464 с.

14. Оксфордский толковый словарь по психологи / под ред. А. Ребера. URL : http://vocabulary.ru/dictionary/487/word.

15. Панасюк Р.В. Еволюційний погляд на дефініцію «інвалідність». Актуальні проблеми психологіï. 2018. Вип. 45. Т. 7. С. 240-252.

16. Байда Л., Красюкова О. Інвалідність та суспільство : навчальний посібник. Київ, 2011. 184 c.

17. Панасюк Р.В. Еволюційний погляд на дефініцію «інвалідність». Актуальні проблеми психології. 2018. Вип. 45. Т. 7. С. 240-252.

18. Корнієнко С. Теоретичний аналіз спеціального понятійного апарату на відповідність завдання забезпечення прав дітей-інвалідів в Україні. Вісник Начіональної академї державного управління. Серія «Соціальна і гуманітарна політика». 2011. № 3. С. 271-277.

19. Стандартні правила забезпечення рівних можливостей для інвалідів : Резолюція Генеральної Асамблеї ООН від 20 груд. 1993 р. № 48/96/1. URL : https://zakon.rada.gov.ua/laws/ show/995_306.

20. Технології роботи організаційних психологів : навчальний посібник / за наук. ред. Л.М. Карамушки. Київ : ІНКОС, 2005. 366 с.

21. Капська А.Й. Соціальна педагогіка : підручник / за ред. проф. А.Й. Капської ; 4-е вид., виправ. та доп. Київ : Центр учбової літератури, 2009. 488 с.

22. Специальная педагогика / под ред. Н.М. Назаровой ; 2-е изд. стереотип. Москва : Академия, 2001. $400 \mathrm{c.}$ $2000.384 \mathrm{c}$.

23. Сирота И.М. Право и социальное обеспечение в Украине. Харьков : Одиссей,

24. Козуб І.І. Права людини чи інваліда? Право України. 2010. № 1. С. 122-127.

25. Красномовець В.А. Інвалідність: відображення соціального явища у теоретичних поняттях у контексті людського розвитку. URL : http://www.nbuv.gov.ua/PORTAL/Soc_Gum/Vpu/ Ekon/2009_7/39.pdf.

26. Красномовець В.А. Інвалідність: відображення соціального явища у теоретичних поняттях у контексті людського розвитку. URL : http://www.nbuv.gov.ua/PORTAL/Soc_Gum/Vpu/ Ekon/2009 7/39.pdf.

27. Тарасенко В.С. Правове забезпечення соціального захисту дітей-інвалідів в Україні : дис. ... канд. юрид. наук : 12.00.05. Одеса, 2005. 198 с.

28. Байда Л., Красюкова О. Інвалідність та суспільство : навчальний посібник. Київ, 2011. $184 \mathrm{c}$.

29. Мілушина М.О. Основні дефініції дослідження осіб з обмеженими фізичними можливостями. Вісник Дніпропетровського університету ім. Альфреда Нобеля. Серія «Педагогіка $і$ психологія». 2013. № 1(5) 80. С. 79-83.

30. Назарова Л.П. Методика развития слухового восприятия у детей с нарушением слуха. Москва : Корекцион. педагогика, 2001. 287 с.

31. Медвідь А.О. Соціальний захист бездомних осіб і безпритульних дітей: дис. ... к. ю. н. : 12.00.05; Нац. ун-т «Одеська юридична академія». Одеса, 2015. 240 с. 